\title{
Impact of Judicious Supplementation of Nutrients on Physico-Chemical Parameters of Garden Pea (Pisum sativum L.)
}

\author{
Yogesh Pawar*, L. R. Varma ${ }^{2}$, T. Thomson ${ }^{3}$ and B. M. Nandre \\ Department of Vegetable Science, College of Horticulture, S. D. Agricultural University, \\ Sardarkrushinagar, (Gujarat) India-385 506, India \\ *Corresponding author
}

\begin{abstract}
A B S T R A C T
To eradicate the malnutrition problem and improve the protein deficient diet and low yield of pea, it is necessary to increase pea production per unit area on sustainable basis to meet the requirement of increasing population of the nation. In view of that, experiment was executed to examine the response of four different organic manures viz. farmyard manure, vermicompost, castor cake and poultry manure as a source of nitrogen with or without chemical fertilizers like phosphorus and potassium and biofertilizer i.e. PSB were tested during the year of 2012 and 2013. The outcome of experiment revealed that, significantly maximum protein content $(23.09 \%, 22.98 \%$ and $23.04 \%)$ was recorded with $\mathrm{T}_{18}$ during both the years of experimentation (2012 and 2013) and in pooled analysis, respectively. The significantly maximum length of pod $(8.23 \mathrm{~cm})$ was noted with $\mathrm{T}_{12}$ (Recommended dose of N as Farm Yard Manure + P and K) in the year 2012. Whereas, during year 2013 and in pooled data $\mathrm{T}_{16}$ recorded maximum length of pod $(8.38 \mathrm{~cm}$ and $8.38 \mathrm{~cm}$ ). Significantly maximum ascorbic acid $(10.17 \mathrm{mg} / 100 \mathrm{~g}$ and $10.08 \mathrm{mg} / 100 \mathrm{~g})$ was recorded with $\mathrm{T}_{16}$ during the year 2012 and in pooled analysis, respectively, however, $\mathrm{T}_{15}$ (Recommended dose of $\mathrm{N}$ as Vermicompost + P and K + PSB) with $10.10 \mathrm{mg} / 100 \mathrm{~g}$ during the year 2013.
\end{abstract}

\section{Introduction}

India is thickly populated country and most of the residents of this country are vegetarian. The growing of vegetable is the most intensive, profitable and most remunerative and also may be adopted with small holders with profitable and gaining business. Garden pea (Pisumsativum L. var. hortense) is a second important food legume of the world. The green and dry foliage are used as cattle fodder and green pods of vegetable pea are highly nutritive so, preferred for culinary purpose. The high percentage of digestible protein (7.2 g), carbohydrates (15.8 g), Vitamin A (139 I.U.), Vitamin C (9 mg), magnesium (34 mg) and phosphorus (139 mg) per $100 \mathrm{~g}$ of edible portion (Gopalan, 2007).

The food legumes are builder and restorer of soil fertility has long been recognized due to their unique ability of symbiotic nitrogen 
fixation. This also makes them the most important and useful component of a cropping system in the present context of energy crisis. To eradicate the low yield of pea,s uccess of Indian agriculture depends heavily on use of fertilizers. To compensate the short supply and to mitigate recent price hike in inorganic fertilizers, use of indigenous sources helps to sustain crop yields but also plays a key role in improving the physical, chemical and biological properties and also increases the efficiency of applied fertilizers (Singh and Biswas, 2000).

To sustain soil health and benign environment there is a need for standardization the conjunctive use of organic and inorganic sources of nutrition in order to increase the productivity and alternately improving the soil health (Sharma and Chauhan, 2011; Bahadur et al., 2006; Rajput and Kushwah, 2005). The concept of nutrient management is gaining considerable momentum today but negligible study has been conducted so, the present investigation was planned and executed on garden pea.

\section{Materials and Methods}

The investigation executed at Department of Vegetable Science, College of Horticulture, S. D. Agricultural University, Sardarkrushinagar. The four different organic manures viz. farmyard manure, vermicompost, castor cake and poultry manure as a source of nitrogen with or without chemical fertilizers like phosphorus and potassium and biofertilizer i.e. PSB were tested during the rabi season of the year 2012 and 2013. The promising variety of garden pea i.e. Bonneville was taken for investigation. The experiment was laid out in a Randomized Block Design with three replications. Total eighteen different treatments were employed in the experiment are as follows.

Table.1

\begin{tabular}{|c|c|c|c|}
\hline Treat. No. & \multicolumn{3}{|l|}{ Treatments } \\
\hline $\mathbf{T}_{1}$ & \multicolumn{3}{|c|}{ Recommended dose of NPK (25:70:50 kg/ha) } \\
\hline $\mathbf{T}_{2}$ & \multicolumn{3}{|c|}{ Farm Yard Manure $15 \mathrm{t} / \mathrm{hectare}+$ Recommended dose of NPK } \\
\hline $\mathbf{T}_{3}$ & \multicolumn{3}{|c|}{ Recommended dose of $\mathrm{N}$ as Vermicompost } \\
\hline $\mathbf{T}_{4}$ & \multicolumn{3}{|c|}{ Recommended dose of $\mathrm{N}$ as Farm Yard Manure } \\
\hline $\mathbf{T}_{5}$ & \multicolumn{3}{|c|}{ Recommended dose of $\mathrm{N}$ as Castor Cake } \\
\hline $\mathbf{T}_{6}$ & \multicolumn{3}{|c|}{ Recommended dose of $\mathrm{N}$ as Poultry Manure } \\
\hline $\mathbf{T}_{7}$ & \multicolumn{3}{|c|}{ Recommended dose of $\mathrm{N}$ as Vermicompost + PSB } \\
\hline $\mathbf{T}_{8}$ & \multicolumn{3}{|c|}{ Recommended dose of $\mathrm{N}$ as Farm Yard Manure + PSB } \\
\hline $\mathbf{T}_{9}$ & \multicolumn{3}{|c|}{ Recommended dose of $\mathrm{N}$ as Castor Cake + PSB } \\
\hline $\mathbf{T}_{10}$ & \multicolumn{3}{|c|}{ Recommended dose of $\mathrm{N}$ as Poultry Manure + PSB } \\
\hline $\mathbf{T}_{11}$ & \multicolumn{3}{|c|}{ Recommended dose of $\mathrm{N}$ as Vermicompost $+\mathrm{P}$ and $\mathrm{K}$} \\
\hline $\mathbf{T}_{12}$ & \multicolumn{3}{|c|}{ Recommended dose of $N$ as Farm Yard Manure $+P$ and $K$} \\
\hline $\mathbf{T}_{13}$ & \multicolumn{3}{|c|}{ Recommended dose of $\mathrm{N}$ as Castor Cake $+\mathrm{P}$ and $\mathrm{K}$} \\
\hline $\mathbf{T}_{14}$ & \multicolumn{3}{|c|}{ Recommended dose of $\mathrm{N}$ as Poultry Manure $+\mathrm{P}$ and $\mathrm{K}$} \\
\hline $\mathbf{T}_{15}$ & \multicolumn{3}{|c|}{ Recommended dose of $\mathrm{N}$ as Vermicompost $+\mathrm{P}$ and $\mathrm{K}+\mathrm{PSB}$} \\
\hline $\mathbf{T}_{16}$ & \multicolumn{3}{|c|}{ Recommended dose of $\mathrm{N}$ as Farm Yard Manure $+\mathrm{P}$ and $\mathrm{K}+\mathrm{PSB}$} \\
\hline $\mathbf{T}_{17}$ & \multicolumn{3}{|c|}{ Recommended dose of $\mathrm{N}$ as Castor Cake + P and $\mathrm{K}+\mathrm{PSB}$} \\
\hline $\mathbf{T}_{18}$ & \multicolumn{3}{|c|}{ Recommended dose of $\mathrm{N}$ as Poultry Manure $+\mathrm{P}$ and $\mathrm{K}+\mathrm{PSB}$} \\
\hline \multicolumn{4}{|l|}{ Note: } \\
\hline \multicolumn{2}{|c|}{ Biofertilizers (Seed treatment) } & & @ 20 ml per kg seed \\
\hline \multicolumn{2}{|c|}{ Biofertilizers (Soil treatment) } & & @1.25 liter per hectare \\
\hline
\end{tabular}


The soil status of experimental field given in Table 1.

To raise the crop recommended package of practices were followed. The different varieties were evaluated on the basis of physico-chemical performance. The various parameters were recorded from ten randomly selected tagged plants. The mean data were subjected to statistical analysis following analysis of variance technique (Gomez and Gomez, 1984).

\section{Physical parameters}

Significantly the highest weight of pod(7.33 $\mathrm{g}, 7.00 \mathrm{~g}$ and $7.17 \mathrm{~g}$ ) was observed with $\mathrm{T}_{18}$ (Recommended dose of $\mathrm{N}$ as poultry manure $+\mathrm{P}$ and $\mathrm{K}+\mathrm{PSB}$ ) during both the years of experimentation (2012 and 2013) and in pooled analysis, respectively and it was statistically at par with $\mathrm{T}_{15}$ and $\mathrm{T}_{14}$ during the year 2012 and all other treatments except $T_{1}$, $\mathrm{T}_{5}$ and $\mathrm{T}_{10}$ during 2013, whereas, $\mathrm{T}_{16}, \mathrm{~T}_{14}$ and $\mathrm{T}_{15}$ in pooled analysis.

The lowest weight of $\operatorname{pod}(5.67 \mathrm{~g})$ was observed with $\mathrm{T}_{11}$ (Recommended dose of $\mathrm{N}$ as vermicompost $+\mathrm{P}$ and $\mathrm{K}$ ) during the year 2012, while, $\mathrm{T}_{1}$ (Recommended dose of NPK 25:70:50 kg/ha), $\mathrm{T}_{5}$ (Recommended dose of $\mathrm{N}$ as castor cake) and $\mathrm{T}_{10}$ (Recommended dose of $\mathrm{N}$ as poultry manure $+\mathrm{PSB}$ ) recorded the lowest weight of pod $(6.00 \mathrm{~g})$ during the year 2013 and $\mathrm{T}_{5}$ (Recommended dose of $\mathrm{N}$ as castor cake) showed similar trend with6.00 g in pooled analysis.

The interaction between year and treatment was found significant with respect to weight of pod $(\mathrm{g})$.

The yield attributes significantly increased with application of recommended dose of Nitrogen through poultry manure in combination of recommended Phosphorus and potash as chemical fertilizers and PSB. It might probably be due to the higher percentage of macro and micro nutrient content in poultry manure than other supplemented sources. Similar finding were obtained by Rajput and Kushwah (2005), Meena et al., (2007), Chopra et al., (2008) and Nandi (2008) in garden pea.

The data presented in the table indicated that the effect of various treatments on number of grains per pod was found to be nonsignificant during the year of 2012, 2013 and in pooled data. However, maximum number of grains per pod $(6.67,7.00$ and6.83) was recorded with $\mathrm{T}_{16}$ (Recommended dose of $\mathrm{N}$ as farm yard manure $+\mathrm{P}$ and $\mathrm{K}+\mathrm{PSB}$ ) in the year 2012, 2013 and in pooled analysis, respectively.

The minimum number of grains per pod (5.33 and 5.67) was recorded with $\mathrm{T}_{4}$ (Recommended dose of $\mathrm{N}$ as farm yard manure) and $\mathrm{T}_{11}$ (Recommended dose of $\mathrm{N}$ as vermicompost $+\mathrm{P}$ and $\mathrm{K}$ ) during the year 2012 and 2013, respectively. In pooled analysis, similar trend (6.00) was observed with $\mathrm{T}_{1}$ (Recommended dose of NPK 25:70:50 kg/ha), $\mathrm{T}_{4}$ (Recommended dose of $\mathrm{N}$ as farm yard manure), $\mathrm{T}_{7}$ (Recommended dose of $\mathrm{N}$ as vermicompost $+\mathrm{PSB}$ ) and $\mathrm{T}_{11}$ (Recommended dose of $\mathrm{N}$ as vermicompost + $\mathrm{P}$ and $\mathrm{K})$.

This is genetic behaviour of the variety therefore no any significant variation observed.

Significantly maximum length of pod (8.23 $\mathrm{cm}$ ) was noted with $\mathrm{T}_{12}$ (Recommended dose of $\mathrm{N}$ as farm yard manure $+\mathrm{P}$ and $\mathrm{K}$ ) in the year 2012 and which was statistically at par with all other treatments except $T_{1}$ and $T_{5}$. Whereas, during year 2013, $\mathrm{T}_{16}$ (Recommended dose of $\mathrm{N}$ as farm yard manure $+\mathrm{P}$ and $\mathrm{K}+\mathrm{PSB}$ ) recorded maximum 
length of pod $(8.38 \mathrm{~cm})$ and it was statistically at par with all other treatments except $\mathrm{T}_{1}, \mathrm{~T}_{6}$ and $\mathrm{T}_{10}$. In pooled data, similar trend $(8.38$ $\mathrm{cm})$ was observed with $\mathrm{T}_{16}$ and it was statistically at par with all other treatments except $\mathrm{T}_{1}, \mathrm{~T}_{5}$ and $\mathrm{T}_{6}$.

The minimum length of pod $(6.25 \mathrm{~cm})$ was observed with $\mathrm{T}_{5}$ (Recommended dose of $\mathrm{N}$ as castor cake) during the year 2012, whereas, $\mathrm{T}_{6}$ (Recommended dose of $\mathrm{N}$ as poultry manure) showed similar trend $(6.58 \mathrm{~cm}$ and $7.02 \mathrm{~cm}$ ) during the year 2013 and in pooled analysis, respectively.

The interaction effect between year and treatment was found significant and it indicated inconsistency in effect of treatments on length of pod $(\mathrm{cm})$ though the effect of treatments remained same in both the years.

The improvement in pod characters like length as a result of FYM application might be due to cumulative effect of improvement in vegetative growth and yield attributes (Mujumdar et al., 2002 and Rana et al., 2009 in garden pea). These results are in close agreement with those reported by Nandi (2008), Chattooet al., (2009), Jaipaul et al., (2011), Singh et al., (2011) and Sepehya et al., (2012) in garden pea.

A perusal of data from table revealed that the effect of various treatments on thickness of pod was found to be non-significant during both the years of experimentation (2012 and 2013) and in pooled data. However, the maximum thickness of pod $(11.70 \mathrm{~mm})$ was recorded with $\mathrm{T}_{15}$ (Recommended dose of $\mathrm{N}$ as vermicompost $+\mathrm{P}$ and $\mathrm{K}+\mathrm{PSB}$ ) during the year 2012, whereas, $\mathrm{T}_{18}$ (Recommended dose of $\mathrm{N}$ as poultry manure $+\mathrm{P}$ and $\mathrm{K}+\mathrm{PSB}$ ) recorded maximum thickness of pod (12.77 $\mathrm{mm}$ and $12.14 \mathrm{~mm}$ )during the year 2013 and in pooled analysis, respectively.

The minimum thickness of pod was recorded with $\mathrm{T}_{13}$ (Recommended dose of $\mathrm{N}$ as castor cake $+\mathrm{P}$ and $\mathrm{K}$ ) i.e. $10.48 \mathrm{~mm}, \mathrm{~T}_{17}$ (Recommended dose of $\mathrm{N}$ as castor cake $+\mathrm{P}$ and $\mathrm{K}+\mathrm{PSB}$ ) with $10.48 \mathrm{~mm}$ and $\mathrm{T}_{5}$ (Recommended dose of $\mathrm{N}$ as castor cake) with $10.58 \mathrm{~mm}$ in the year 2012, 2013 and in pooled data, respectively.

The interaction between year and treatment was found non-significant and showed inconsistency of effect of treatments on thickness of $\operatorname{pod}(\mathrm{g})$.

\section{Chemical parameters}

Significantly maximum protein (23.09\%, $22.98 \%$ and $23.04 \%$ ) content of pods was recorded with $\mathrm{T}_{18}$ (Recommended dose of $\mathrm{N}$ as poultry manure $+\mathrm{P}$ and $\mathrm{K}+\mathrm{PSB}$ ) during both the years of experimentation (2012 and 2013) and in pooled analysis, respectively. The treatment $T_{18}$ was significantly superior over all other treatments.

Minimum protein $(22.68 \%)$ content of pods was recorded with $\mathrm{T}_{6}$ (Recommended dose of $\mathrm{N}$ as poultry manure) in the year 2012, whereas, during $2013 \mathrm{~T}_{1}$ (Recommended dose of NPK $25: 70: 50 \mathrm{~kg} / \mathrm{ha}$ ) with $22.55 \%$ while, $\mathrm{T}_{3}$ (Recommended dose of $\mathrm{N}$ as Vermicompost), $\mathrm{T}_{4}$ (Recommended dose of $\mathrm{N}$ as farm yard manure) and $\mathrm{T}_{6}$ (Recommended dose of $\mathrm{N}$ as poultry manure) showed similar trend with $22.66 \%$ in pooled analysis.

The interaction between year and treatment failed to exert any significant influence on protein $(\%)$ content of pods.

This can be explained on the basis as demonstrated by Koshalendra et al., (1992) that the increase in protein content of beans due to the application of organics. They attributed this firstly to the increase in the $\mathrm{N}$ content of beans and $\mathrm{N}$ being an integral part of enzymes and amino acids, plays a major role in synthesis of proteins and secondly due 
to the increase in the availability of $\mathrm{P}$ with the application of poultry manure, which help in energy storage and transfer in form of ADP and ATP, which are essential for protein biosynthesis. These results are in conformity with those of Vimala and Natrajan (2000), Meenaet al., (2007) and Sharma et al., (2011).

The data given in Table 3 indicated that various treatments significantly influenced the ascorbic acid (mg/100g) content of pods during both the years of experimentation (2012 and 2013) and in pooled analysis. Significantly maximum ascorbic acid (10.17 $\mathrm{mg} / 100 \mathrm{~g}$ ) content of pods was recorded with $\mathrm{T}_{16}$ (Recommended dose of $\mathrm{N}$ as farm yard manure $+\mathrm{P}$ and $\mathrm{K}+\mathrm{PSB}$ ), which was statistically at par with $\mathrm{T}_{17} \mathrm{~T}_{18}, \mathrm{~T}_{15}, \mathrm{~T}_{12}$ and $\mathrm{T}_{10}$ during the year 2012. However, the maximum ascorbic acid (10.10 $\mathrm{mg} / 100 \mathrm{~g})$ content of pods was recorded with $\mathrm{T}_{15}$ (Recommended dose of $\mathrm{N}$ as vermicompost $+\mathrm{P}$ and $\mathrm{K}+\mathrm{PSB}$ ) and which was statistically at par with $\mathrm{T}_{18}, \mathrm{~T}_{16} \mathrm{~T}_{13}, \mathrm{~T}_{17}$, $\mathrm{T}_{12}$ and $\mathrm{T}_{14}$ during the year 2013 , whereas, $\mathrm{T}_{16}$ (Recommended dose of $\mathrm{N}$ as farm yard manure $+\mathrm{P}$ and $\mathrm{K}+\mathrm{PSB}$ ) in pooled analysis with $10.08 \mathrm{mg} / 100 \mathrm{~g}$ and it was statistically at par with $\mathrm{T}_{15} \mathrm{~T}_{17} \mathrm{~T}_{18}, \mathrm{~T}_{12}, \mathrm{~T}_{13}, \mathrm{~T}_{14}$ and $\mathrm{T}_{10}$.

The minimum ascorbic acid $(9.57 \mathrm{mg} / 100 \mathrm{~g})$ content of pods was recorded with $\mathrm{T}_{1}$ (Recommended dose of NPK 25:70:50 kg/ha) during the year 2012, 2013 and in pooled analysis, while, $\mathrm{T}_{7}$ (Recommended dose of $\mathrm{N}$ as vermicompost + PSB) showed similar trend with $9.57 \mathrm{mg} / 100 \mathrm{~g}$ during the year 2013.

The interaction between year and treatment was found non-significant and showed inconsistency of treatments on ascorbic acid $(\mathrm{mg} / 100 \mathrm{~g})$.

Because of slow but continuous supply of all major and micro-nutrients, which might have helped in the assimilation of carbohydrates and in turn synthesis of ascorbic acid. Bahadur et al., (2006) in pea and Jaipaul et al., (2011) also noticed significantly higher vitamin $\mathrm{C}$ content in garden pea where organic manures were applied in combination with inorganic nutrient sources.

A perusal of data revealed that the effect of various treatments on reducing sugar was found to be non-significant during both the years of experimentation (2012 and 2013) and in pooled data. However, the highest reducing sugar content of pods $(2.93 \%)$ was recorded with $\mathrm{T}_{18}$ (Recommended dose of $\mathrm{N}$ as poultry manure $+\mathrm{P}$ and $\mathrm{K}+\mathrm{PSB}$ ) during the year 2012, 2013 and in pooled analysis. Whereas, $\mathrm{T}_{17}$ (Recommended dose of $\mathrm{N}$ as castor cake $+\mathrm{P}$ and $\mathrm{K}+\mathrm{PSB}$ ) indicated similar trend with $2.93 \%$ during the year 2013 .

The lowest reducing sugar content of pods was recorded with $\mathrm{T}_{10}$ (Recommended dose of $\mathrm{N}$ as poultry manure + PSB) i.e.2.82 \%, $\mathrm{T}_{5}$ (Recommended dose of $\mathrm{N}$ as castor cake) with $2.81 \%$ and $\mathrm{T}_{2}$ (Farm yard manure 15 t/ha + Recommended dose of NPK) with 2.83 $\%$ in the year 2012, 2013 and in pooled analysis, respectively.

The interaction effect between year and treatment on reducing sugar (\%) produced non-significant results.

Similar results were reported that increase in reducing sugar content with the application of NPK was due to the close relationship between the carbohydrate metabolism and formation of reducing sugar. Organic sources enhanced the nutrient availability in soil and carbohydrate metabolism, which resulted in higher reducing sugar content. These findings are in accordance with those of Bahadur et al., (2006), Meena et al., (2007) and Chopra et al., (2008) in garden pea. It is obvious from the data presented in the table that the effect 
of various treatments on non-reducing sugar (\%)content of pods was found to be nonsignificant during both the years of experimentation (2012 and 2013) and in pooled data. However, the highest nonreducing sugar content of pods $(1.67 \%, 1.70$ $\%$ and $1.69 \%$ ) was observed with $\mathrm{T}_{18}$ (Recommended dose of $\mathrm{N}$ as poultry manure + P and K + PSB) during the year 2012, 2013 and in pooled analysis, respectively. The lowest non-reducing sugar content of pods (1.49\% and $1.52 \%$ ) was observed with $\mathrm{T}_{7}$ (Recommended dose of $\mathrm{N}$ as vermicompost + PSB) during the year 2012 and in pooled analysis, respectively; while during year 2013 $\mathrm{T}_{1}$ (Recommended dose of NPK (25:70:50 $\mathrm{kg} / \mathrm{ha}$ ) showed similar trend with $1.55 \%$.

The interaction effect between year and treatment on non-reducing sugar (\%) produced non-significant results.

It is obvious from the data presented in the table that the effect of various treatments on total sugar (\%)content of pods was found to be non-significant during both the years of experimentation (2012 and 2013) but significant in pooled data. However, the highest total sugar content of pods $(4.61 \%$, $4.63 \%$ and $4.62 \%$ ) was recorded with $\mathrm{T}_{18}$ (Recommended dose of $\mathrm{N}$ as poultry manure + P and K + PSB) during the year 2012, 2013 and in pooled analysis, respectively and it was found statistically at par with all other treatments except $T_{1}, T_{2}, T_{3}$ and $T_{7}$ in pooled data.

The lowest total sugar content of pods (4.36 $\%$ ) was observed with $\mathrm{T}_{1}$ (Recommended dose of NPK 25:70:50 kg/ha), $\mathrm{T}_{2}$ (Farm yard manure 15 t/ha + Recommended dose of $\mathrm{NPK}$ ) and $\mathrm{T}_{3}$ (Recommended dose of $\mathrm{N}$ as vermicompost) during the year 2012, while, $\mathrm{T}_{1}$ showed similar trend with $4.40 \%$ and 4.38 $\%$ during the year 2013 and in pooled analysis, respectively.

The interaction effect between year and treatment on total sugar (\%) produced nonsignificant results.

Table.1 Physico-chemical properties of the experimental soil

\begin{tabular}{|c|c|c|c|}
\hline S.N. & Properties & Status & Methods employed \\
\hline 1 & Textural class & Sandy loam & International pipette method (Piper, 1966) \\
\hline 2 & Soil $\mathrm{pH}$ & 7.5 & Potentiometric method (Jackson, 1973) \\
\hline 3 & Organic carbon $(\%)$ & 0.15 & $\begin{array}{l}\text { Walkley and Black's rapid titration method } \\
\text { (Jackson, 1973) }\end{array}$ \\
\hline 4 & Available $\mathrm{N}\left(\mathrm{kg} \mathrm{ha}^{-1}\right)$ & 138 & $\begin{array}{l}\text { Alkaline permanganate method (Jackson, } \\
\text { 1973) }\end{array}$ \\
\hline 5 & Available $\mathrm{P}_{2} \mathrm{O}_{5}\left(\mathrm{~kg} \mathrm{ha}^{-1}\right)$ & 31.20 & Olsen's method (Jackson, 1973) \\
\hline 6 & Available $\mathrm{K}_{2} \mathrm{O}\left(\mathrm{kg} \mathrm{ha}^{-1}\right)$ & 281 & Flame photometer method (Jackson, 1973) \\
\hline
\end{tabular}


Table.2 Influences of integrated use of organic and inorganic sources of nutrients on physical parameters of garden pea

\begin{tabular}{|c|c|c|c|c|c|c|c|c|c|c|c|c|}
\hline \multirow[t]{2}{*}{ Treatments } & \multicolumn{3}{|c|}{$\begin{array}{c}\text { Weight of pod } \\
(\mathrm{g})\end{array}$} & \multicolumn{3}{|c|}{ Number of grains per pod } & \multicolumn{3}{|c|}{ Length of pod (cm) } & \multicolumn{3}{|c|}{ Thickness of pod (mm) } \\
\hline & 2012 & 2013 & Pooled & 2012 & 2013 & Pooled & 2012 & 2013 & Pooled & 2012 & 2013 & Pooled \\
\hline $\mathbf{T}_{1}$ & 6.33 & 6.00 & 6.17 & 5.67 & 6.33 & 6.00 & 7.01 & 7.18 & 7.10 & 10.99 & 11.07 & 11.03 \\
\hline $\mathbf{T}_{2}$ & 6.00 & 6.33 & 6.17 & 6.33 & 6.33 & 6.33 & 7.42 & 7.58 & 7.50 & 10.53 & 10.94 & 10.74 \\
\hline $\mathbf{T}_{3}$ & 6.00 & 6.67 & 6.33 & 6.33 & 6.67 & 6.50 & 7.78 & 7.80 & 7.79 & 10.64 & 10.56 & 10.60 \\
\hline $\mathbf{T}_{4}$ & 6.00 & 6.67 & 6.33 & 5.33 & 6.67 & 6.00 & 7.33 & 7.37 & 7.35 & 10.61 & 11.27 & 10.94 \\
\hline $\mathbf{T}_{5}$ & 6.00 & 6.00 & 6.00 & 6.33 & 6.33 & 6.33 & 6.25 & 8.21 & 7.23 & 10.65 & 10.51 & 10.58 \\
\hline$T_{6}$ & 6.00 & 6.33 & 6.17 & 6.00 & 7.00 & 6.50 & 7.45 & 6.58 & 7.02 & 11.23 & 10.95 & 11.09 \\
\hline $\mathbf{T}_{7}$ & 6.00 & 6.33 & 6.17 & 5.67 & 6.33 & 6.00 & 7.47 & 7.79 & 7.63 & 10.76 & 10.82 & 10.79 \\
\hline $\mathbf{T}_{8}$ & 6.00 & 6.67 & 6.33 & 6.33 & 6.33 & 6.33 & 7.46 & 7.55 & 7.51 & 11.03 & 12.19 & 11.61 \\
\hline $\mathbf{T}_{9}$ & 6.33 & 6.33 & 6.33 & 6.00 & 6.33 & 6.17 & 7.88 & 7.48 & 7.68 & 10.88 & 10.53 & 10.71 \\
\hline $\mathbf{T}_{10}$ & 6.67 & 6.00 & 6.33 & 6.33 & 6.33 & 6.33 & 8.18 & 7.08 & 7.63 & 10.69 & 11.20 & 10.95 \\
\hline$T_{11}$ & 5.67 & 6.67 & 6.17 & 6.33 & 5.67 & 6.00 & 7.90 & 7.71 & 7.81 & 10.68 & 10.96 & 10.82 \\
\hline$T_{12}$ & 6.00 & 6.33 & 6.17 & 6.00 & 6.67 & 6.33 & 8.23 & 7.48 & 7.86 & 11.06 & 11.39 & 11.23 \\
\hline $\mathbf{T}_{13}$ & 6.00 & 6.67 & 6.33 & 6.00 & 6.33 & 6.17 & 8.01 & 7.71 & 7.86 & 10.48 & 10.98 & 10.73 \\
\hline $\mathbf{T}_{14}$ & 6.67 & 7.00 & 6.83 & 6.00 & 6.67 & 6.33 & 7.64 & 8.00 & 7.82 & 10.74 & 10.98 & 10.86 \\
\hline $\mathbf{T}_{15}$ & 7.00 & 6.33 & 6.67 & 6.00 & 6.33 & 6.17 & 8.00 & 8.11 & 8.05 & 11.70 & 11.56 & 11.63 \\
\hline $\mathbf{T}_{16}$ & 6.00 & 7.67 & 6.83 & 6.67 & 7.00 & 6.83 & 8.08 & 8.38 & 8.23 & 11.28 & 11.29 & 11.29 \\
\hline $\mathbf{T}_{17}$ & 5.67 & 6.67 & 6.17 & 6.00 & 6.67 & 6.33 & 8.01 & 7.69 & 7.85 & 10.74 & 10.48 & 10.61 \\
\hline $\mathbf{T}_{18}$ & 7.33 & 7.00 & 7.17 & 6.33 & 6.67 & 6.50 & 7.90 & 8.30 & 8.10 & 11.50 & 12.77 & 12.14 \\
\hline S.Em \pm & 0.24 & 0.29 & 0.27 & 0.44 & 0.35 & 0.40 & 0.35 & 0.33 & 0.34 & 0.45 & 0.50 & 0.47 \\
\hline C.D. at $5 \%$ & 0.69 & 0.84 & 0.75 & NS & NS & NS & 0.99 & 0.94 & 0.95 & NS & NS & NS \\
\hline \multicolumn{13}{|c|}{ Interaction: YX T } \\
\hline S.Em \pm & & & 0.42 & & & 0.31 & & & 0.46 & & & 0.32 \\
\hline C.D. at $\overline{5} \%$ & & & 1.20 & & & NS & & & 1.31 & & & $\mathrm{NS}$ \\
\hline
\end{tabular}


Table.3 Influences of integrated use of organic and inorganic sources of nutrients on chemical parameters of garden pea

\begin{tabular}{|c|c|c|c|c|c|c|c|c|c|c|c|c|c|c|c|}
\hline \multirow[t]{2}{*}{ Treatments } & \multicolumn{3}{|c|}{ Protein (\%) } & \multicolumn{3}{|c|}{ Ascorbic acid (mg/100g) } & \multicolumn{3}{|c|}{ Reducing sugar (\%) } & \multicolumn{3}{|c|}{$\begin{array}{c}\text { Non-reducing sugar } \\
(\%)\end{array}$} & \multicolumn{3}{|c|}{ Total sugar (\%) } \\
\hline & 2012 & 2013 & Pooled & 2012 & 2013 & Pooled & 2012 & 2013 & Pooled & 2012 & 2013 & Pooled & 2012 & 2013 & Pooled \\
\hline $\mathbf{T}_{1}$ & 22.83 & 22.55 & 22.69 & 9.57 & 9.57 & 9.57 & 2.86 & 2.84 & 2.85 & 1.50 & 1.55 & 1.53 & 4.36 & 4.40 & 4.38 \\
\hline $\mathbf{T}_{2}$ & 22.81 & 22.65 & 22.73 & 9.63 & 9.60 & 9.62 & 2.84 & 2.82 & 2.83 & 1.51 & 1.62 & 1.57 & 4.36 & 4.45 & 4.40 \\
\hline $\mathbf{T}_{3}$ & 22.69 & 22.63 & 22.66 & 9.63 & 9.63 & 9.63 & 2.86 & 2.82 & 2.84 & 1.50 & 1.67 & 1.59 & 4.36 & 4.49 & 4.43 \\
\hline $\mathbf{T}_{4}$ & 22.69 & 22.64 & 22.66 & 9.60 & 9.70 & 9.65 & 2.85 & 2.87 & 2.86 & 1.54 & 1.67 & 1.61 & 4.40 & 4.53 & 4.47 \\
\hline $\mathbf{T}_{5}$ & 22.85 & 22.64 & 22.75 & 9.73 & 9.67 & 9.70 & 2.88 & 2.81 & 2.85 & 1.63 & 1.65 & 1.64 & 4.51 & 4.46 & 4.49 \\
\hline $\mathbf{T}_{6}$ & 22.68 & 22.64 & 22.66 & 9.73 & 9.63 & 9.68 & 2.84 & 2.86 & 2.85 & 1.60 & 1.66 & 1.63 & 4.44 & 4.52 & 4.48 \\
\hline $\mathbf{T}_{7}$ & 22.88 & 22.69 & 22.79 & 9.77 & 9.57 & 9.67 & 2.89 & 2.87 & 2.88 & 1.49 & 1.56 & 1.52 & 4.38 & 4.43 & 4.40 \\
\hline $\mathbf{T}_{8}$ & 22.91 & 22.68 & 22.79 & 9.73 & 9.67 & 9.70 & 2.88 & 2.87 & 2.88 & 1.60 & 1.57 & 1.59 & 4.48 & 4.44 & 4.46 \\
\hline $\mathbf{T}_{9}$ & 22.81 & 22.73 & 22.77 & 9.83 & 9.73 & 9.78 & 2.89 & 2.85 & 2.87 & 1.59 & 1.62 & 1.61 & 4.48 & 4.47 & 4.48 \\
\hline $\mathbf{T}_{10}$ & 22.83 & 22.73 & 22.78 & 9.87 & 9.67 & 9.77 & 2.82 & 2.91 & 2.87 & 1.56 & 1.64 & 1.60 & 4.38 & 4.55 & 4.47 \\
\hline $\mathbf{T}_{11}$ & 22.85 & 22.74 & 22.80 & 9.77 & 9.67 & 9.72 & 2.87 & 2.89 & 2.88 & 1.60 & 1.62 & 1.61 & 4.47 & 4.51 & 4.49 \\
\hline $\mathbf{T}_{12}$ & 22.84 & 22.71 & 22.78 & 9.90 & 9.93 & 9.92 & 2.92 & 2.87 & 2.89 & 1.57 & 1.69 & 1.63 & 4.49 & 4.56 & 4.52 \\
\hline $\mathbf{T}_{13}$ & 22.84 & 22.67 & 22.75 & 9.80 & 10.00 & 9.90 & 2.89 & 2.90 & 2.89 & 1.62 & 1.63 & 1.63 & 4.51 & 4.53 & 4.52 \\
\hline $\mathrm{T}_{14}$ & 22.88 & 22.71 & 22.80 & 9.83 & 9.93 & 9.88 & 2.91 & 2.87 & 2.89 & 1.64 & 1.65 & 1.65 & 4.55 & 4.52 & 4.54 \\
\hline $\mathbf{T}_{15}$ & 22.92 & 22.81 & 22.87 & 10.00 & 10.10 & 10.05 & 2.91 & 2.93 & 2.92 & 1.54 & 1.69 & 1.62 & 4.45 & 4.62 & 4.54 \\
\hline $\mathbf{T}_{16}$ & 22.94 & 22.73 & 22.83 & 10.17 & 10.00 & 10.08 & 2.90 & 2.91 & 2.91 & 1.61 & 1.60 & 1.61 & 4.51 & 4.51 & 4.51 \\
\hline $\mathbf{T}_{17}$ & 22.92 & 22.80 & 22.86 & 10.10 & 9.97 & 10.03 & 2.89 & 2.93 & 2.91 & 1.65 & 1.59 & 1.62 & 4.53 & 4.53 & 4.53 \\
\hline $\mathbf{T}_{18}$ & 23.09 & 22.98 & 23.04 & 10.00 & 10.07 & 10.03 & 2.93 & 2.93 & 2.93 & 1.67 & 1.70 & 1.69 & 4.61 & 4.63 & 4.62 \\
\hline S.Em \pm & 0.02 & 0.05 & 0.04 & 0.11 & 0.11 & 0.11 & 0.03 & 0.04 & 0.03 & 0.05 & 0.04 & 0.04 & 0.06 & 0.06 & 0.06 \\
\hline C.D. at $5 \%$ & 0.06 & 0.13 & 0.10 & 0.32 & 0.33 & 0.32 & NS & NS & NS & NS & NS & $\mathrm{NS}$ & NS & NS & 0.16 \\
\hline \multicolumn{16}{|c|}{ Interaction: YX T } \\
\hline S.Em \pm & & & 0.04 & & & 0.08 & & & 0.02 & & & 0.04 & & & 0.04 \\
\hline C.D. at $5 \%$ & & & NS & & & NS & & & NS & & & NS & & & NS \\
\hline
\end{tabular}


Koshalendra et al., (1992) have reported that total polysaccharides and sugars in crops increased due to application of organics, which resulted due to the higher availability of Phosphorus which is a constituent of ADP, ATP and other high energy compounds. Moreover, due to organic sources alongwith chemical fertilizers there was increase in reducing and non-reducing sugar, so the increase in total sugar content in pea seed was natural. These findings are in accordance with those of Khurana and Chatterjee (2003), Bahadur et al., (2006), Meena et al., (2007) and Chopra et al., (2008) in garden pea.

\section{References}

Bahadur, A., Singh, J., Singh, K.P. and Rai, Mathura 2006. Effect of plant growth, yield and quality attributes of garden pea as influenced by organic amendments and biofertilizers. Indian Journal of Horticultural. 63 (4): 464466.

Chattoo, M.A., Ahmad, N., Khan, S.H., Sidique, S.H. and Hussan, K. 2009. Residual effect of organic manures and inorganic fertilizers on succeeding crop pea (Pisum sativum L.) cv. Bonneville. The Asian Journal of Horticulture. 4 (2): 299-304.

Chopra, S., Sharma, J.P. and Kumar, K. 2008. Influence of integrated nutrient management on growth, yield and quality of vegetable pea. Journal of Plant Science Research. 24(2): 199-202.

Gomez, K.A. and A.A Gomez. 1984. Statistical procedures for agricultural research, $2^{\text {nd }}$ edition. John Wiley and Sons, New York, pp.680.

Gopalan, C., S.B.V. Rama, S.C. Bala subramanian. 2007. Nutritive Value of Indian Foods- revised edition. National Institute of Nutrition, Indian Council of Medical Research, Hyderabad, India. P. 50.
Jackson, M.L. 1973. Soil Chemical analysis. Prentice Hall of India Pvt. Ltd., New Delhi.

Jaipaul, S., Dixit A. and Sharma, A.K. 2011. Growth and yield of capsicum (Capsicum annum) and garden pea (Pisum sativum) as influenced by organic manures and biofertilizers. Indian Journal of Agricultural Science. 81 (7): 637-642.

Khurana, N. and Chatterjee, C. 2003. Impact of copper stress on metabolism and seed quality of pea (Pisum sativum L.). Indian Journal of Horticulture. 60(2): 167-170.

Koshalendra, T.; Solankey, B.S. and Shinde, D.A. 1992. Effect of phosphorus levels and genotypes on quality of soybean seeds. Legume Research. 15(2): 76-80.

Meena, R.N., Singh, Y., Singh, S.P., Singh, J.P. and Singh, K. 2007. Effect of sources and level of organic manures on yield, quality and economics of garden pea (Pisum sativum L.). Vegetable Science. 34 (1): 60-63.

Nandi, A. 2008. Effect of organic manures and amendments with or without fertilizers on performance of garden pea (Pisum sativum L.). Veg. Sci. 35 (2): 208-209.

Piper, C.S. 1966. Soil and plant analysis. The University of Adelaide Academic Press, N.Y., Australia, pp. 47-80.

Rajput, R.L. and Kushwah, S.S. 2005. Effect of integrated nutrient management on yield of pea (Pisum sativum). Legume Res. 28 (3): 231-232.

Rana, M.C., Sharma, G.D., Bindra, A.D. and Angiras, N.N. 2009. Effect of farm yard manure, fertilizer levels and plant density on the performance of garden pea (Pisum sativum L.) in high hill dry temperate conditions. Himachal $J$. Agric. Res. 35 (1): 21-23.

Sepehya, S., Bhardwaj, S.K., Dixit, S.P. and Dhiman, S. 2012. Effect of integrated 
nutrient management on yield attributes, yield and NPK uptake in garden pea (Pisum sativum L.) in acid Alfisol. J. Food Leg. 25 (3):247-249.

Sharma, U. and Chauhan, J.K. 2011. Influence of integrated use of inorganic and organic sources of nutrients on growth and production of pea. Journal of Farm Sciences. 1 (1): 14-18.

Singh, G.B. and Biswas, P.P. 2000. Balanced and integrated nutrient management for sustainable crop production. Indian Journal of Fertilizers 45(5): 55-60.

Singh, R.K., Singh, R.P., Choudhary, S.K. and Upadhyay, P.K. 2014. Effect of organic sources of nutrients on soil quality, productivity and economics of late sown chickpea and fieldpea. Green Farming 5(5): 796-800.

Singh, R.N., Singh, S., Prasad, S.S., Singh, V.K. and Kumar, P. 2011. Effect of integrated nutrient management on soil fertility, nutrient uptake and yield of rice-pea cropping system on an upland acid soil of Jharkhand. J. Indian Soc. Soil Sci. 59 (2):158-163.

Vimala, B. and Natarajan, S. 2000. Effect of nitrogen, phosphorus and biofertilizers on pod characters, yield and quality of pea (Pisum sativum L. spphortense). South Indian Horticulture, 48: 60-63.

\section{How to cite this article:}

Yogesh Pawar, L. R. Varma, T. Thomson and Nandre, B. M. 2020. Impact of Judicious Supplementation of Nutrients on Physico-Chemical Parameters of Garden Pea (Pisum sativum L.). Int.J.Curr.Microbiol.App.Sci. 9(05): 626-635. doi: https://doi.org/10.20546/ijcmas.2020.905.069 